\title{
Global Education: What Teachers Can Do in the Classrooms
}

\author{
Julia Eka Rini
}

\begin{abstract}
This article will give examples of what teachers of second language can do to implement global education, especially peace and environmental education in the classrooms in university level. This is an attempt to give a new meaning to the same materials used in the classrooms. Besides enabling the students to acquire and use a second language, teachers can make the students aware of the importance of environment. Moreover, teachers can initiate to spread peace in the small world of a classroom and a chain reaction is expected to happen from this small world to the bigger world outside the classroom. The skill and content courses used as examples here are taken from the ones used at English Department at Petra Christian University.
\end{abstract}

Keywords: Global education, peace education, environmental education, global issues / problems, foreign/second language teaching/teachers, students, world citizens, classroom, skill courses, content courses.

According to JALT homepage, in the background, global issues are defined as world problems such as war, hunger, poverty, discrimination, and environmental destruction as well as to concepts such as peace, justice, human rights, world citizenship, social responsibility and international understanding. In the same homepage global education is defined as an exciting approach to foreign language teaching which aims at enabling students to effectively acquire and use a foreign language while empowering them with knowledge, skills and commitment required by world citizens for the solution of global problems. In this homepage also questions concerning the responsibility of language teachers concerning global issues can be found.

On the first reading of the definitions of global education and global issues and also global education in second language teaching by Jacobs and Cates in this edition too, I have the idea that actually, without realizing it or not, teachers of second language are not that strange to global education, especially peace and environmental education. Some materials used in reading courses, for instance, talk about pollution. When global issues have been incorporated in the materials of second language istruction, teachers have talked about global issues in the classroom and thus carry out global education, probably without realizing it. Therefore, it is possible to implement global education, especially peace and environmental education, because global issues concerning peace and environment can be inserted both in skill courses as well as in content courses. 


\section{Skill Courses}

Skill courses are a wide open area to global education. Since topic and materials can be taken from textbooks and authentic materials, teachers will not lack materials about global problems. Newspapers and magazines are full of global problems, concerning both peace and environment, for example the fight and murder among American teens, pollution etc.

At Petra English Department, for example, environmental issues are incorporated in skill courses, like reading. Reading materials can be taken from various sources, because a lot of reading materials include environmental issues. Teachers and students can discuss materials like recycling, pollution, and sewage treatments thoroughly and students can be encouraged to give comments. If the students are active in class, they can be encouraged to give comments orally. If they cannot or are reluctant to do so, they can write their comments and then read them aloud so that each student in the classroom can know what his or her classmates' opinion about that topic. Then the teacher can also give his or her opinion and insert global education there.

In speaking courses, topics like litter, pollution, and slum areas are not something new. At Petra these topics dominate Speaking IV and students of speaking IV are able to discuss and debate about these topics. In speaking courses teachers actually have greater chance and more time to insert global education, not only environmental but also peace education, because teachers and students can interact more freely without being required to discuss a topic from one piece of reading only. They can refer to different readings of the same topic. Students can also be assigned to make a speech about global issues in speaking VI, for example, when they have to present a topic.

In pronunciation class peer teaching in the classroom will also make students feel that teachers trust them and make students understand their peers' difficulties. For example, in teaching pronunciation, teachers can ask students to teach other students who have difficulties to pronounce certain sounds. This can also create a nice atmosphere in class. And this, I say, is the beginning of peace.

In listening, in case there are no ready-to-listen cassettes in the library, reading materials concerning environmental issues can be taken and a native speaker working in the university can be asked to read them and recordings can be made in the language lab. Students can be asked to write comments about it also. Teachers can make comprehension questions and discuss the answers and insert comments and opinions.

In writing, the same thing can be done for peace education. If the national situation is not yet certain, like in Indonesia, topics in writing can be about the political situation, for example the Chinese and indigenous relationship. This is one among the topics suggested in writing IV and also one of the topics in Speaking V in 1998-1999. If some students are still interested in this topic, probably they can also discuss it in the last speaking course, speaking VI, when they have to give a speech on a certain topic, especially on current issues. If international conflict is one of the themes for peace education, then certainly national conflict is one good topic to discuss. Students can be asked to write problem-solution essays about teens fight at high schools etc. 


\section{Content Courses}

Although content courses seem to give less opportunity for teachers to insert global education, it is not something impossible. Both in literature and linguistic courses global education can be inserted.

In content courses, like literature, conflicts exist most of the time in novels, dramas and probably also poems. This is exactly where teachers can promote peace education because they do not only talk about the cause and effect of conflicts, but they can also talk about how to solve conflicts. Conflicts between man and man or man and the society are some of the topics discussed in novels or dramas. They can talk about the characters first and after that relate it with the students' lives as well. They can also talk about conflicts among members of a family often bring deep hurt to a person, if the texts happen to talk about it. This might be an example for students to solve conflics with their families. At least, teachers can show the students examples how to analyze causes of conflicts and make them know the results of conflict and also how to solve them. The most important thing is that it is related to their lives, not just written on paper. By discussing with their friends and teachers how to solve conflicts happen in the story, students can be made active to look for solution of conflicts. At least, their experience of discussing it with their friends and teachers will make them aware that conflicts can be solved by, first, discussing it with people around them. This makes them open to others and vice versa.

Even in linguistics, such as language acquisition, lecturers can show and emphasize the universality of mankind. They can give examples that "all infants make cooing and babbling noises during the first few months (Yule, 1996: 176), although they live in different parts of the world and their parents speak different languages. From this one proof only, they can show how actually people, in spite of their differences, are still the same human beings. Teachers can point out later that stages, not only cooing, in first language acquisition are more or less the same. This holds true with the communication strategies they use when they learn second language. Students, through discussing with their classmates and reading the books, can realize that they struggle learning something new in more or less the same way like others in other parts of the world. The fact that they acquire language, whether the first or the second language in more or less the same way, will promote peace among themselves in this competitive world, because they will be able to see some similarities among themselves.

Being advisors of students who write theses, for example, really needs patience and understanding. Students writing theses usually undergo great stress. What they need is actually more of encouragement and motivation rather than the problem of the thesis, although some students need more guidance with the academic problem. Sometimes the willingness to listen is the most important thing that students need. Sharing problems with the advisor can motivate students to continue writing and face the problems they encounter. Probably a lot of people still question Krashen's affective filter hypothesis, but in my experience as a lecturer this is not only true in language acquisition, but also in language instruction. This is another good occasion where teacher can promote peace education.

Environmental education can also be carried out here, for example, by asking the students to use used paper for the draft of the theses. If teachers can make students concern about this issue, probably when the students graduate and work, they will be 
able to encourage others to do the same thing. If they will become teachers, they will, in turn, be able to encourage their students to do the same.

\section{Challenges and Opportunities}

So far, probably teachers just stop at the point that it is a problem or even a global problem; they probably do not go a little bit further with aiming at making the students concerned or subtly provoking the students to do something about global problems. All of the discussions and debates and the comments given and done in the classroom can make students aware and teachers can emphasize that these problems are the world's problem. And as citizens of the earth, they need to, at least, know that those are also their problems. Teachers can point out that what students can do personally to help protect the environment, such as to remind themselves and probably their friends to really use paper efficiently, for example both sides of the same piece of paper, or just simple practices like picking up the soft drink can if they happen to see it near the garbage can and not inside in the gargabe can. Teachers can trigger students to participate in doing something for the environment by doing this small and simple practices first. Probably this can trigger students to think about what they can do as a group to create a better environment, for example, help maintain the campus green by planting more trees etc. Teachers just have to make students aware first that this is also their problem and they have to do something about it, first in a small scope and later on a bigger one. Or they can ask students to do something and integrate it as class project. The examples given here, both the courses and what teachers can do in the classroom, are taken from several courses and I am sure that this is not an exhaustive list. Teachers will be able to see what they can do in the subject(s) they teach.

Above all that, teachers' attitude towards the students are the living proofs and examples that can change and motivate students to provide peace and to pay attention to others and to the environment. Teachers can be "attention and peace providers" as well as information providers. Students bringing problems to the classrooms will not be interested in the subjects taught in class if they do not see and experience the real truth about what teachers talk and teach--peace, solution of conflicts etc. How can they be motivated to solve others' conflicts if their own conflicts with their parents, with themselves and others, especially with the teachers are neglected. Teachers, of course, cannot give personal consultation during teaching, but at least they can try to smile or give extra attention, if they feel something unusual with the students. Sometimes a comment like 'That's a good question' means a lot to a student. This is probably a simple example and it is not something new to teachers as far as a students is concerned, but probably teachers do not realize that this one simple comment can make this one student do the same to others. This one simple action is expected to have a chain reaction both inside and outside the classroom.

Since second language instruction in universities is "an activity located within education" (Littlewood, in Brumfit, 1991, p. 15), what happens in a second language classroom should be related to these three purposes of education (Littlewood, p.15): first, to transmit valued knowledge and culture; second, to develop learners as individuals and third, to prepare learners as members of society. Since global education is concerned with global problems and students are members of the small world of a classroom and of a bigger world outside the classroom, students, if not the teachers also, will benefit a lot from global education. First, they will have broader 
perpective about the world, because they receive extra knowledge besides foreign language. Second, with their knowledge of one foreign language, its culture, the global problems and probably the solutions, they will be able to have more chance to express themselves as individuals. Third, the knowledge of the global problems and probably the solution will prepare them as better members of society.

\section{Conclusion}

Several points about global education in the classroom can be taken. First, how far teachers can do in carrying out global education can range from just making the students aware of the existence of the problems until being successful in encouraging students to do something for this lovely earth and its inhabitants. From the examples we have seen that global education can be inserted in second language teaching although bigger portion deals with awareness, attitude and concern than participation. If the former does not exist, then we cannot expect the latter. Second, inserting global education in second language instruction does not mean changing all the materials; probably teachers just need to provide additional materials. Third, if teachers open the door for global education, they will help students' developments as individuals by providing more perspective on the world and giving them more opportunities to future learning. They will also give them more opportunities to do something for mankind. However, global education will just be a term, new and exciting, but will not change anything for the sake of mankind and for a better world if teachers and students do not start from the small world of a classroom. Hopefully this small world can influence the bigger world outside the classroom, the global village, and we can sing together Richard and Robert Sherman's song 'It's a small

\section{References}

Jacobs, George and Kip Kates. (1999). Global education in second language learning. In Kata. Surabaya: Petra Christian University.

Japan association for language teaching's global issues special issues group-http://langue.hyper.chubu.ac.jp./jalt/nsig/globalissues/gi.html

Littlewood, William. (1991). Curriculum design in applied linguistics and English language teaching. Roger bowers and christopher brumfit. Eds. London: Macmillan Publishers Limited.

Petunjuk Akademik Jurusan Sastra Inggris Fakultas Sastra Universitas Kristen Petra. Surabaya: U.K Petra. 1995.

Yule, George. The study of language. Cambridge: Cambridge University Press. 1996. 